\title{
Ernest Hemingway's Idiosyncratic Style and Its Reflection in Russian Translation
}

\author{
Irina Orujova ${ }^{1}$ \\ ${ }^{1}$ Department of English Translation, Azerbaijan University of Languages, Baku, Azerbaijan \\ Correspondence: Irina Orujova, Department of English Translation, Azerbaijan University of Languages, Baku, \\ Azerbaijan. E-mail: irinaorujova@gmail.com
}

Received: January 7, 2017 Accepted: March 2, 2017 Online Published: April 13, 2017

doi:10.5539/ijel.v7n3p215 URL: http://doi.org/10.5539/ijel.v7n3p215

\begin{abstract}
The creative legacy of great American modernist writer Ernest Hemingway presents a huge interest both for the linguists and literary critics. His books have been translated into a great majority of languages, his creative activity and personal style of writing has been investigated by literary critics and linguists at different times, his life and personality has been described extensively by his biographers, researchers and people who knew him personally. Nevertheless, both his biography and the value of his literary works have always been the object of debates. Scholars have always argued about the linguistic value of his style of writing; for some linguists Hemingway's style seemed too simple to be analysed. Others, and they are in majority, find his style complicated, idiosyncratic and heterogeneous with the very peculiar choice of language means. Therefore, translation of Hemingway's stories and novels creates challenges for translators trying to achieve the greatest degree of adequacy. Contrary to the opinion of some scholars and critics, such as D. H. Lawrence, Louis Kronenberger, Schuyler Ashley and others, Hemingway's prose is rich in figures of speech, such as metaphor, metonymy, repetition, simile and others. While translating Hemingway's prose into Russian, the translators managed to find the adequate solution to the stylistic difficulties of the original by means of resorting to analogue translation, compensation and other techniques analysed in this article. The article focuses on revealing the linguistic and cultural complexity of adequate transformation of Ernest Hemingway's short stories into Russian, paying special attention to his unique style. The article also emphasizes the fact of neutralization and decoration of some original phrases used by translators into Russian which didn't affect the level of adequacy of the target text.
\end{abstract}

Keywords: writing style, translation adequacy, figures of speech, translation loss, equivalent, analogue, compensation, neutralization

\section{Introduction}

Translation is an activity that is growing at a phenomenal speed in today's globalized world. It has a huge effect on everybody's life. The diversity of the translated texts stipulates the difference of the peculiar features of the functional styles, which, in its turn, calls forth the specific requirements to translation of each of them. Any task, any activity to be solved in translation, the semantic, stylistic or the aesthetic one should be achieved only by means of the language. Language is the expression and the repository of culture; the words, as the minimal units of translation are naturally bound up with the culture and, therefore, they may cause difficulties in transference in their totality to another language.

Typological differences between English and Russian languages cause certain difficulties the translators come across while translating literary works. It goes without saying that Ernest Hemingway belongs to the greatest American modernist writers of the XX century. His literary heritage has been widely investigated and criticized both by American and foreign critics. Hemingway's prose has been translated into all the languages of the world. Nevertheless, scholars are still arguing about the value of his style, especially the style of his early works - his short stories. Some linguists and critics consider the style of his short stories too simple, while the others point out the versatile character of the figures of speech and other language means used in his works. Consequently, the analysis of the author's unique style of writing never loses its novelty and attractiveness.

Translation of fiction is both science and art; it should be devoid of standard approaches, still, it should be based on scientific requirements of the theory of translation. That is why translators of fiction have to be experienced professional experts. In translation of E. Hemingway's stories and novels translators might have resorted to the 
unpredictable solutions, not foreseen by the previous experience and not outlined in the translation studies textbooks. The correct overcoming of the challenges caused by the uniqueness of E. Hemingway's style of writing leads to the adequate understanding of the content and stylistic colouring of the original text.

The first translation of Ernest Hemingway's prose into Russian appeared in the Soviet Union in 1934. Before that Hemingway's works had been unknown to the Soviet readership. In the absence of translations a small number of professionals had heard of his growing international reputation and quite a few people had read his works in English. Due to that, the general impression of Hemingway was very vague and he was usually associated with the symbol of 'decadence'. The situation changed abruptly in 1934 when his stories appeared first in the anthology of American short stories and then in various magazines. Finally, a collection made up of selections from four of his books was published under the title "Death in the Afternoon".

In 1935 his novel "The Sun Also Rises" was published in the USSR, in 1936 "A Farewell to Arms" came out, followed by the translation of "To Have and Have Not" in 1938, and in 1939 "The Fifth Column" and "The First Thirty-Eight Stories" were translated and published. Beginning from these publications the translated stories and novels in all the languages of the Soviet Union were published with great frequency. The Soviet readers discovered the craft of Ernest Hemingway's literary work due to the artful translation of such proficient translators into Russian as V. Toper, E. Kalashnikova, H. Volzhina, O. Kholmskaya, N. Daruzes, E. Romanova. In Azerbaijan the readers can also read Hemingway's stories and novels translated into Azerbaijani by R. Gurbanov, I. Shukurov, H. Hajiyev, J. Mamedgulizadeh, M. Suleymanov. Most of them belonged to the translation school of Ivan Kashkeen who established the scientifically based criteria for translation of fiction and was one of the first Soviet critics of E. Hemingway.

Critical articles of Soviet critics on various aspects of Hemingway's life and creative activity followed Kashkeen's numerous critical and analytical essays and articles about E. Hemingway. However, not all the areas of writer's idiosyncratic language have got the proper consideration. The author of the article undertook a critical review of translations of E. Hemingway's stories analyzing semantic and stylistic faithfulness of translations and their closeness to the original. In an attempt to find some novelty in the study of Hemingway's language the best solution seemed to be the stories of the book called In Our Time as they have not been studied thoroughly yet. This book of collection of stories was disregarded by many critics for a long time, as it was considered a fragmentary collection of separate stories connected by interchapters. But it is the unique language of these interchapters and their interconnection with the stories or chapters that attracted the attention of the author. These interconnections in combination with the innovative, unusual style of the writer, the style which is often called "formative" by some critics, leads to a very difficult understanding of the book. To compare the evolution of Hemingway's style two other stories of his second creative period were analyzed- "The Short Happy Life of Francis Macomber" and "The Snows of Kilimanjaro".

Analysis of the correspondences between the original - the short stories written by E. Hemingway —and their translation into Russian, finding out the difference of the forms this correspondence can acquire in some concrete cases is only possible with application of the method of comparative translation analysis which consists of the analysis of the form and the contents of the text of translation and their comparison with the form and the contents of the text of the original. The two texts, the source and the original, represent the objective facts available for observation and analysis. In the process of translation the correspondences between the two texts become obvious. While comparing the two texts the inner mechanism of translation is revealed, the equivalent units of language are defined, as well as shifts in the form and the contents; all these can be made possible while changing the language units of the original by the equivalent language units of the text of translation.

The comparative translation analysis is not limited by the area of words and grammar, rather, it includes stylistics; moreover, the stylistic aspect of the linguistic problem of translation is of primary importance and interest, that's why the article touches upon the stylistic aspect of translation of E. Hemingway's short stories, first of all.

\section{Stylistic Peculiarities of E. Hemingway's Short Stories}

Ernest Hemingway's writing style reflects his unique talent formed under the influence of his idiosyncratic personal qualities and rich life experience; his style stands out as innovative, revolutionary for his time. Hemingway entered the world of literature in the 1920's with his book of short stories "In Our Time", published in 1925 and followed by the novels "The Sun Also Rises" (1926) and "A Farewell to Arms" (1929). For almost forty years of his literary activity Ernest Hemingway created a great many books which won him world fame. Each of these books carries its absolutely special world with its unique motifs and coloring. Many of his stories represent the portrayals of the world of lost values and lost illusions, which is the result of the imprint of the war the writer fought at, consequences of the serious wound and psychological injury. All these factors couldn't but stipulate 
Hemingway's choice of language means.

Hemingway's style, though seemingly simple, represents an organic combination of substance and expression, but the choice of his linguistic means to achieve the desired effect doesn't always comply with the norms of a standard notion of style exercised at that time. The explanation for this phenomenon lies partly in the intention of the author, his feelings and emotions related to the real world which surrounded him. The journalistic experience of writing for newspapers helped E. Hemingway to be precise and perfectly realistic in his descriptions, it helped him to see everything he came across distinctly, memorize and fix it without distortions, affectation and eloquence of expression. As Hemingway mentioned himself, he had to "...use vigorous English. Be positive, not negative" (Fenton, 1996). Besides, this style demanded not to use slang and to use only a limited number of adjectives, especially such "extravagant" ones as "splendid, gorgeous, grand, magnificent".

Hemingway's early book of stories "In Our Time" possesses some distinctive features of his raw, formative style. The book was written by Hemingway at the beginning of his literary career, when he was still experimenting with stylistic devices, looking for something special, unique and impressive. His successful and rich experience as a reporter for such newspapers as the Kansas City Star and the Toronto Star, as the famous American literary critic Milton A. Cohen thinks, "did more to shape his style and tone than any other influence" (Cohen, 2005). Writing for those newspapers, Hemingway learned to use the journalistic style: short declarative sentences, short first paragraphs, and unadorned, matter-of-fact language. The stories of "In Our Time" are unified by the common theme built on a unique model containing "the careful artistry and the central vision of the world and the human condition which characterize Hemingway's writing from beginning to end" (Burhans, 1983). The stories and the interchapters represent the stylistic experiments in the narrative voice, mode, perspective, and sentence rhythm.

The idiosyncratic manner of arrangement and composition of the book which is permeated by the peculiar expression of time and space relations, along with the arts of economy and revision, are characteristic of Hemingway's short stories. In Our Time, as Robert M. Slabey put it, "is more than a fresco of the 'way it was'; the book possesses a highly subtle unity of structure, coherence of meaning, and development of theme" (Slabey, 1983). The stories of In Our Time alternate with sixteen short sketches, also called interchapters, miniatures, or vignettes. Most of them represent scenes of cruelty and violence.

One of the most remarkable features of Hemingway's artistic manner is based on revealing the genuine sense of his creativity, the mastery of his art not directly, not through author's direct remarks and his characters' words, but through the so-called implications, the sub-text, and the covert message, sometimes hidden very deeply. The writer managed to hide the social and historical coloring in these implications, or implicatures. The combination of subjective and objective features in the narration of the stories stipulates the great role of the implicatures based on the interaction of what is said and what is hidden. Hemingway reveals his artistic manner not directly, through the author's remarks and characters' words, but indirectly, through the implied sub-text. Nevertheless, the author's evaluation of described events, his attitudes to the characters' images and the themes hidden in the implicatures make understanding of the intention of the plot and the characters more difficult, which, in its turn, result in the loss of stylistic information. The implicatures in Hemingway's stories can be revealed both within the whole text, on the compositional level, and on the lexical level, by means of using the figures of speech while describing people, animals, natural phenomena, creating the specific emotional atmosphere. The lexical figures of speech employed by the author create huge opportunities for actualization of a neutral word as a stylistically marked element, which lead to the enhancement of the meaningfulness of the text.

E. Hemingway kept to the well-known artistic principle which is mostly used in play-writing, but it is also applicable to the other artistic genres - the principle of introducing into the fiction work only the elements which will be useful in the future narration or development of the events. As a highly disciplined author E. Hemingway created his economically composed books on this very principle. But from time to time he acted quite contrary to it. Spare details seemingly unnecessary happened to permeate into his stories and novels, simply because 'it was so', as they are the elements of the real world. These details are never mentioned further, and the reader might think that the author shared these details with them by absolutely arbitrary observation. But the effect of this technique makes the reader feel as if he himself noticed this accidental, insignificant fact, and consequently, he, the reader, has seen this scene himself. This effect is possible to achieve only through the right choice of words and peculiar structures of sentences.

In order to impart more expressiveness to the word of art the writers resort to various means of creation of the text imagery. An image in fiction is "the representation of a general thing through an individual one, an abstract thing through a concrete one, and a conceptual thing through a perceptual, visual and tangible" (Kukharenko, 1979). Thus, Hemingway in his stories uses a special double-plane structure consisting of the text and subtext, 
understatement or implicature. The distant realization of meaning, figures of speech, artistic details and symbols are among Hemingway's other favorite means of image conveyance. All Hemingway's short stories contain two distinct and parallel narrative lines, the primary one that reflects the realistic world, and the secondary one connected with some religious myth, national or ethnic belief or universally accepted associations linked with some objects or animals.

Combination of realistic and symbolic images found in the interpersonal context characterizes pragmatic approaches to interpretation. The perception of symbols is often subject to the reader's personal vision of some phenomenon, his/her world outlook, as well as the cultural standards and reader's education and general background knowledge. Symbols are met in any kind of communicative act in the process of interaction. They are very elusive; it is difficult to fix them according to the norms of the language as symbols allude, suggest but not make explicit statements. The linguistic symbols take shape only within the context of a writer who uses the symbol metonymically for the purpose of creating an emotive effect imposed upon the reader. Still, the meanings of most of the symbols are culturally conditioned, from which follows that they are comprehensible only to the members of a particular cultural community. For example, the notion of fire in many cultural contexts relate to domestic comfort, warmth and hospitality. In some nations fire is used to conduct certain religious rituals, and in this respect it signifies abundant harvest, good health, success and so on. In Azerbaijani culture fire worshipping also meant a lot of good things - it was linked to the fire of spirit, religious zeal. The image of the fire burning from natural oil and gas even found its way in the very name of the country. But fire can represent destruction according to some contexts and cultural perceptions. Similarly, rain in many cultures suggests fertility, abundant harvest, joy and happiness. In Hemingway's works rain always stands for sorrow, grief, separation, even death in some contexts. Even the title of one of the stories "Cat in the Rain" implies that there is something more than just a cat which is soaking under the rain. The cat's crouched position in the abovementioned story is symbolically connected to the protagonist's uncertain position in life, and to a greater degree it is related to the discontented feelings of his wife who is longing for a child or somebody to care about.

Symbolism is an inevitable, integral part typical to the compact, economical style in which Hemingway's short stories are written. For example, in "In Our Time" the events in the interchapters stand in the foreground, but the author provides the readers with the chance to feel the meaning of the vignettes. We can feel symbolic implications in almost each chapter. The symbolic implications are foregrounded by means of the following stylistic features: by the redundant repetition of the phrase "there were" and "the courtyard", by the unusual syntactic link between the sentences and by the reversal of the cause-and-effect relationship.

The following phrases can help build the image through symbolic implication: "pools of water", "wet dead leaves", and so on. These images evoke other images in the minds of the readers-dead people, pools of blood. The interpretation of these foregrounded symbols is possible due to stylistic repetition and redundancy which add the semantic significance to the symbolic objects. The six ministers, once very important people, now are treated as useless leaves. The symbols of death and suffering penetrate into almost all the vignettes:

They shot six cabinet ministers at half-past six in the morning against the wall of the hospital. There were pools of water in the courtyard. There wet dead leaves on the paving of the courtyard. It rained hard. All the shutters of the hospital were nailed shut. One of the ministers was sick with typhoid. Two soldiers carried him downstairs and out into the rain. They tried to hold him up against the wall but he sat down in a puddle of water. The other five stood very quietly against the wall. Finally the officer told the soldiers it was no good trying to make him stand up. When they fired the first volley he was sitting down in the water with his head on his knees.

The passage contains the violated order of cause-and-effect; "pools of water" is the effect of "It rained hard", so "wet dead leaves" symbolize dead bodies soaked in blood. On the other hand, the courtyard symbolizes a bloody killing ground, and the hospital with the nailed shutters - a grave or a tomb. These symbols contribute to the gloomy description of the executions, intensifying the effect. Hemingway uses the images of water and rain in the situations where death is inevitable, though as a hackneyed symbol, water usually signifies purification and renewal of life as compared to dryness and drought, dangerous and sometimes even fatal for humans. The image of home in such stories as "The Three-Day Blow", "Big Two-Hearted River", "A Clean, Well-Lighted Place" and some other stories bear positive associations: security, well-being, comradeship, safety, joy. However, the bulls in the bullfighting vignettes symbolize strength and vulnerability at the same time, they represent a complex symbol, as the bulls in the vignettes are all eventually killed, and occasionally they kill the matadors. The bull as a symbol of strength always appealed to Hemingway, and killing of a magnificent and powerful beast is associated with the proof of man's superiority. The stories dealing with the bullfight depict violence, disaster, chaos, and sudden death; violence and death were raised by the writer into the art. 
...Then he cursed the bull, flopped the muleta at him, and swung back from the charge his feet firm, the muleta curving and at each swing the crowd roaring... When he started to kill it was all in the same rush...

The characters themselves in Hemingway's stories also serve the sources of symbolism reflecting writer's inner feelings and attitudes. Inner, psychological conflicts of Hemingway's protagonists are sometimes revealed by means of correlative mythological symbols, expressed implicitly as accompanying explicit actions. The reader can feel the symbolization of the protagonists through the narrator's voice as well. An example of it may be found in "The Snows of Kilimanjaro" where the protagonist-Harry is dying and he remarks about death using metaphorical paraphrase just before he loses consciousness:

He had just felt death come by again...

Because, just then, death had come and rested its head on the foot of the cot and he could smell its breath.

In this story Hemingway uses a number of other symbols, such as vultures, hyenas, and the dead leopard, which are connected with death, as the main character is dying throughout the whole story. On the whole, E. Hemingway's short stories are full of symbols, some are contrasting the images of death and well-being, and some represent either valor or suffering. The symbolic depiction in the short stories is achieved by means of metaphoric, metonymic usage, sometimes by similes or antonomasia (personification). The same technique is obvious when we read the short story named The Short Happy Life of Francis Macomber. Hemingway depicts two people with very different traits by using red color-a symbol of passion and vitality and white color. The brave man's face - white hunter Wilson's face is red- "red faced swine". In contrast coward Macomber is "white-faced". Hemingway associates Wilson with the brave animal - the lion. The lion which is to be killed by Macomber symbolizes the two men's behavior; it manifests Macomber's cowardice, and represents the force which has to be overcome. The lion is the totemistic symbol of Macomber's ultimate new self after he kills the animal. From the point of view of Christian religion lion represents solidarity, love and humility as opposed to isolated individualism and pride.

The juxtaposition of man against the animals is deeply rooted in human's mythological past. Hemingway managed to show the contradiction in man and nature by using a great many symbols, such as plains, rivers, mountains, hills, mud and various animals. The figure of the animal in such a situation bears not only its original metaphorical allusion to man's limitations, but rather, Hemingway ironically represents it as a symbol of man's vulnerability in his strength and cultivation. Landscape settings in Hemingway's stories play a great role for creating the atmosphere, thus the image of dry barren land; lifeless hills create an atmosphere of protagonists' moral crisis and emotional emptiness.

The use of various figures of speech contributes greatly to the authenticity of Hemingway's imagery. Nevertheless, such authenticity is also achieved by means of change of voices and types of narration; it is so complicated and intertwined, and it is typical to almost all the American modernist writers. Hemingway's style is abundant with the alternation of direct discourse and reporting thought, which helps the writer to use the close links between voice, narrative, action and point of view. The peculiar way of changing voices and types of narration is first of all manifested in the instability in the use of personal pronouns:

We must all be cut out for what we do, he thought. However you make your living is where your talent lies. He had sold vitality, in one form or another, all his life and when your affections are too involved you give much better value for the money. He had found that out but he would never write that now, either. No, he would not write that, though it was well worth writing.

This passage from E. Hemingway's story "The Snows of Kilimanjaro" is a vivid representation of the protagonist's inner thought. The entire story is written in such manner, except for the short introduction and the concluding part after the main character's death. The first two sentences of the passage represent free direct thought. The third sentence starts with what might seem the author's comment, but when the third person changes to the second, it becomes clear that the narration is still indirect thought. And, in spite of the third person singular pronoun he, the fourth and the fifth sentences in the passage are also indirect thought of the main character-Harry.

The use of a great number of voices, of diverse layers of language - colloquialisms, dialects, idioms and foreignisms, enabled Hemingway to develop his skill of characterization of language of different people in different situations. The vernacular character of his characters' speech is strengthened by use of syntactical expansiveness and such American idiomatic expressions as "slug", "puked", "crazy drunk", and "hollered", etc. The use of colloquial American English by Hemingway is a powerful narrative device, particularly in the first person voices of young narrators, who speak in slangy, ungrammatical ways, using elliptical, broken sentences and repetitions. In fact, the narrative mode of Hemingway's stories is characterized by abruptness, by the matter-of-fact 
tone, which aggravates the theme of violence and suffering. Another technique used by the author is the beginning in the middle of the event and not identifying narrators, brevity of form in combination with the use of lowercase for chapter headings, titles and names on the title page and lack of quotation marks.

Hemingway's perfect “ear" for conversation, his gift to perceive the nuances of speech resulted in his outstanding skill of dialogue writing. He used a technique of brief exchange of phrases indirectly related to the subject under discussion. Further, each speaker picks up a word or a phrase from the other interlocutor and uses it in his remarks, slightly changing it or adding something. For example:

\section{Well, I said, after all he's just an ignorant Mexican savage.}

Yes, Maera said, and who will kill his bulls after he gets a cogida?

\section{We, I suppose, I said.}

Yes, we, said Maera. We kill the savages'bulls, and the drunkards'bulls, and the riau-riau dancers'bulls. Yes, we kill them. We kill them all right. Yes. Yes. Yes.

Besides peculiar use of dialogue structure, Hemingway's preferences in lexical choice also deserve mentioning. It is natural that translation of colloquial speech is even more difficult than translation of literary texts. In spite of it, translators into Russian could find adequate equivalents or analogues, as with the translation of colloquial words and slang: Oh, am so soused, -Oh! Nu i nakachalsya zhe ya (I am so drunken), grammatically incorrect utterances translated by standard structural patterns: He couldn't hardly lift his arm. -On edva dvigal rukoy -(He could hardly lift his arm), shortened word-forms: They're crooks, ain't they? -Vorye oni ili ne vorye? (Are they thieves or not?), elliptical sentences: Wouldn't give them up. -Ni za chto ne otdavali (They didn't give them away), non-standard colloquial phrases: Cheap at the price. -On esche deshevo otdelalsya (He escaped cheaply), inversion: Nothing you could do about it. -Mi nichego ne mogli podelat (We couldn't do anything), etc.

One of the most characteristic grammatical features of the style of "In Our Time" is sentence structure. The sentences are usually simple, declarative; "It was a frightfully hot day". In some cases Hemingway uses compound sentences with two independent clauses linked by a conjunction: "They rushed in, and the officers came out alone and worked on it". The paragraph structure is based on simple sequence determined by the internal logic of the action or situation. The first sentences of each chapter focus on the event described in it and the further details develop readers' sense of that event. The sentences are linear; one phrase is added to another forming syntactical correlation:

Everybody was drunk. The whole battery was drunk going along the road in the dark. We were going to the Champagne. The lieutenant kept riding his horse out into the fields and saying to him, "I'm drunk, I tell you, mon vieux. Oh, I am so soused."

Very often simple sentences contain clauses that function within a phrase and it burdens the phrase, makes it "heavier", e.g.: "The old men and women, soaked through, walked along keeping the cattle moving."

In some cases subordinate clauses of the sentence-level are introduced by subordinate conjunctions, but participles and infinitives in non-finite clauses don't form subordinate clauses at the sentence level. E.g.: "Too heavy to lift and you could shoot through it and they would have to climb over it."

The verbs forming the predicates, predominantly, compound and compound - complex predicates, are mostly the verbs of motion, such as "come", "trail", "swing", "haul”, etc. By using active verbs, not static ones, or by abundant use of gerunds and present participles Hemingway emphasizes the dynamics or the illusion of movement. For this very reason he transforms verbs into gerunds: "there was a shouting going on", "there was fighting".

The variety and idiosyncrasy of sentence structures used by Hemingway have a great impact on the composition of his stories and on the structure and the character of the paragraph and the supra-phrasal units. Concerning syntactic peculiarities of Hemingway's short stories the syntactic stylistic device named "suspense" should be mentioned. Good examples are chapters 5 and 10: "They shot the six cabinet ministers at half-past six in the morning...", "They whack-whacked the white horse on the legs..." The writer didn't give the answer to the questions: "Who are 'they,", "Who are the six cabinet ministers?", "Where did the event take place?", "When?" and so on. By concealing this information Hemingway "seems to suggest that such murders can take place anywhere and anytime in the world" (Shen, 2005). Dan Shen points to the "reversal of the cause and effect" in Hemingway's vignette: "There were pools of water in the courtyard. There were wet dead leaves on the paving of the courtyard. It rained hard" (Shen, 2005). By changing the order of cause and effect the author emphasizes the significance of "pools of water" and "dead leaves".

The stylistic device Hemingway greatly favors for is repetition which the writer frequently uses to reproduce 
natural colloquial speech. One of the types of repetition he very often employs is syntactical repetition where subordinate clauses of similar type are aligned in sequence. He also repeats the identical sentences with similar openers, building them into a rhetorical construction. The most widely-spread kind of repetitions is his repetition of a key word or phrase with a slight shift of meaning, e.g.: "Everybody was drunk. The whole battery was drunk going along the road in the dark. We were going to the Champagne...I'm drunk, I tell you, mon vieux." "Dear jesus please get me out. Christ please please please christ. If you'll only keep me from getting killed I'll do anything you say... Please, please dear jesus."

Sometimes Hemingway combines several kinds of repetition and then this technique can be revealed throughout a paragraph. Besides achieving the effect of authentic colloquial speech, Hemingway imparts secondary meaning to the whole paragraph. Such is the case with chapter 6 where Nick's head is described in three different positions, showing the difficulty Nick had moving his head and the pain he suffered:

Nick sat against the wall of the church where they had dragged him... He had been hit in the spine... Nick looked straight ahead brilliantly... Nick turned his head carefully and looked at Rinaldi... Nick turned his head carefully away smiling sweatily.

Repetition in Hemingway's short stories is stipulated by the writer's desire to emphasize his ironic or sympathetic attitude towards the character or an ironic event. Frequent repetition of the same word or phrase imparting certain rhythm on the utterance is able to strengthen the emotional influence on the reader, keeping their attention at the characters, their feelings and sufferings. The repetitions Hemingway uses are of different type, some of them are simple lexical repetitions, not fixed in any concrete place of the sentences. Most of the other repetitions are anaphora, epiphora or chain repetition. The variety of writer's repetitions include the repetition of the key word, similar parallel constructions or words belonging to the same part of speech, clauses with the anaphoric use of the same conjunctions, etc.

The syntactic repetition mostly encountered in Hemingway's short stories is the repetition of the parallel constructions in descriptions of events and phenomena where the author avoids using compound syntactic constructions with clauses, substituting them by simple or complex sentences. The phrases repeated at the beginning of the sequence of the clauses - the anaphoric use - turn the sentence into the rhetoric construction. Sometimes the repetition of the key word or phrase is met in slightly changed form, which often introduces some changes in the shade of meaning of the whole utterance. The repeated phrases spoken further in such dialogues constitute links between the sentences, making thematic and structural frames. In some sentences the single repetition reinforces the logical and the emotional implicatures and understatements of the paragraph:

The multilevel repetition facilitates creation of rhythmic idiosyncrasy of the original. The prepositions, for instance, repeated with a slightly irregular interval can also impart certain rhythm to the utterance and bear the function of reinforcing the emphasis and changing the semantics of some prepositional constructions. Lexical repetitions of thematic and key words enrich and alter the meaningful content of the text, facilitate the artistic framing and ideational perception of the imagery of the short story. They not only convey the author's intention, but also create the emotional expressive coloring of the original.

Repetition is closely connected with rhythm which is revealed by Hemingway through unfolding compounds, interspersed with repetition of key words, carefully selected participles stressing the flow of the action. As Sheldon Norman Grebstein noted: "Hemingway's most characteristic rhythms are thus the choppy rhythms of colloquial language rather than the sonorous measures of a latinate high style" (Grebstein, 1974). The events in the stories are presented in their development; sentence structure, sequence of actions are crucial to produce the desired effect and to achieve the aim which Hemingway expressed as "to put down what really happened in action".

For the same purpose, as well as to emphasize the dramatic effect of the event Hemingway resorts to onomatopoeia and alliteration, e.g.: "they all stepped back on the scaffolding back of the drop,... built of oak and steel and

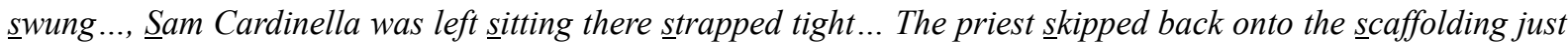
before the drop fell."

The alliterating "s" sound contributes to the staccato rhythm of the passage, adding to the intensification of the tragic event. Hemingway also uses some onomatopoeic relations between the sounds of words and the actions they denote, e.g.: "They whack-whacked the white horse on the legs...", "... and the bull rammed him wham against the wall."

Being an inexperienced writer, Hemingway consciously tested various expressive means and figures of speech in In Our Time, which helped him make more progress later. Even in his early writing career he did it artistically. He used a whole range of different phonetic, lexical, and syntactical devices to communicate the action of war, the 
bullfight, and loss of illusions. That is the reason why the critics called him "a negative writer", as most of his works are permeated by the spirit of violence and death. Nevertheless, his creative activity is not pessimistic; rather, it inspires people in their struggle to remain free and independent. His style is now, according to Nathan Scott, "universally recognized as one of the important innovations of twentieth-century literature and as itself one of the great responses of that literature to an age of war and homelessness and broken faith" (Scott, 1974). Hemingway deeply affected the course of the modern short story. He is justly deemed as a powerful American prose stylist and his collection of stories and vignettes, the complexly unified whole of In Our Time is one of his best creations presenting his world and his art.

\section{The Problem of Adequacy in Russian Translation}

The main aim of any translation is to achieve adequacy of all the levels: lexical, grammatical, and stylistic. However, complete equivalency of translation is not possible due to some natural reasons; therefore, translators should try to avoid any losses in translation. According to Fedorov, an adequate translation is the translation that corresponds to the original in its function and is related to it with the language means (Fedorov, 1968). Adequate transformation of the text is only possible in case all the translation standards are fulfilled on all the levels. A translation is equivalent if all the elements, all the levels of the text have been conveyed adequately and without any losses. Komissarov thinks that adequacy is "something objective, i.e., is the correspondence of objects to the level of adequacy, representing an objective reality not dependent on us" (Komissarov, 2002).

While analyzing the level of adequacy of Hemingway's translated stories into Russian the elements constituting the imagery of the story should be considered. Some of such elements might naturally lose something of their original imagery, the others, on the contrary have been translated with the added emotional coloring. Such difference in the levels of the two texts: the source (the original) text and the target (translated) text are obvious even on the grammatical level, as some sentences have been joined up or broken up into several smaller sentences or clauses. The borders of the paragraphs and supra-phrasal units do not always coincide due to the difference in the systems of the two languages-English and Russian.

\subsection{Translation of Metaphors}

Metaphors is the most important figure of speech to achieve expressiveness and therefore to build the imagery of a literary text. The peculiar use of words, expressions, syntactic structures, as well as figures of speech has always posed a lot of problems to translators. Critics marked that Hemingway's metaphors are not only figure of speech expressed in random words, but rather, they are linguistic embodiment of conceptual metaphors. Hemingway created tangible objects by means of functional, not ornamental metaphors. The conceptual metaphors build throughout the plot or composition, render the themes of war, suffering and loneliness. Nevertheless, it should be admitted that the metaphors Hemingway uses are the means of poetic imagination, despite the fact that many of his metaphors are traditional, trite, "dead" metaphors.

Any study of translation of a literary text should deal with metaphors which create certain imagery; therefore, it is necessary to reveal the level of adequacy of their translation, to find out any distortions, translation shifts and losses, as they have a great impact on the conception of the whole text. While undertaking such an analysis the theory of metaphor translation set by Peter Newmark is very helpful. According to his theory seven variants to translate metaphor are possible; they are the following in the order of preference:

1) Reproducing the same image in the target language;

2) Replacing the image in the source language with a standard TL image;

3) Translation of metaphor by simile;

4) Translation of metaphor by simile plus sense;

5) Conversion of metaphor to sense;

6) Deletion;

7) Same metaphor combined with sense (Newmark, 1988).

For the analysis of metaphors in Hemingway's short stories of the later period, we chose two well-known stories "The Short Happy Life of Francis Macomber" and "The Snows of Kilimanjaro" and compared them with translation into Russian made by Volzhina \& Lorie. The results of the analysis shows that only a small part of all the metaphors, about one-third of them are the traditional metaphors, the others are the genuine, author's metaphors invented by Hemingway. All the metaphors stated below reproduce the same image in translated stories, some of them are explained by sense, i.e., they comply with the fifth version of Newmark's theory: 
The mud castles ants had built—visokiye muraveyniki (high anthills)

Wide boss of horn-cherniy blesk ego rogov (black shimmer of his horns)

The translators managed to convey the imagery of some metaphors by means of the equivalent Russian metaphors which are the standard Russian metaphors, among them are: Cold, hollow fear, He could work the fat off his soul, etc.

In translation of other metaphors the imagery of the original text is conveyed into the imagery of the translation using the translation transformation - the grammatical replacement: the worst sufferers-vsex khuzhe prihoditsya (they get the worst of all); being really a credit to the community-obshestvo mozhet imi gorditsya, (the society can be proud of them):

They're usually the worst sufferers in these little affairs.-Im, pozhaluy, khuzhe vsex prikhoditsya pri etix malenkih semeynih delah.-They get the worst of all at these small little family affairs.

To translate metaphors the other transformations which are lexical transformations were used, nevertheless, the imagery of the original stories has been preserved in them: In a smother of snow-v tuche snega (in a cloud of snow), the rolling high ground - nad volnistoy dolinoy (under a wavy valley).

The most remarkable examples are the sentences which combine extremely complex structures of prolonged metaphors, metonymies woven into epithets and intertwined with compound grammatical structures. It is impossible to translate such sentences avoiding grammatical transformations-replacements, transpositions, omissions and additions, which is evident in translation of many sentences, where the imagery was not affected due to its adequate conveyance by means of equivalent transformation of the sentence.

\subsection{Translation of Metonymy and Simile}

Translation of metonymy can also be based on the principles of imagery transfer mentioned in Newmark's book. Proceeding from the fact that metonymy always compares two objects, their qualities, actions or phenomena, we conclude that translation should also contain comparison. Nevertheless, as it is clear, translation do not always represent the transfer of something from one object to the other adequately. In such cases the neutralization takes place in translation, i.e. the metonymy is conveyed by sense: No pleasure in anything if you mouth it up too much.—Kogda slishkom mnogo govorish o chem-nibud, vsyakoye udovolstviye propadayet. (When you speak too much about something, you lose any pleasure in it).

Having analyzed the cases of metonymic transformations the conclusion is that the translators managed to find the correlates equivalent or close to the original ones, though some of them are combined with sense translation or translation with the use of similes. In spite of the high degree of equivalency of metonymic translation, to avoid losses in translation completely is quite an impossible task; therefore some metonymic expressions were conveyed by descriptive translation combined with various translation transformations:

A big trout broke the surface of the water... another trout broke the water-spina foreli pokazalas iz vodi... plesnula eshe odna forel. (the back of a trout was seen in the water... another trout appeared). He gets a little wild sometimes. - Pravda inogda na nego nakhodit. (Sometimes he is wrong in his head).

Simile is another trope significant for creation of imagery. In this research we took into consideration three following components of simile: the signifier (the vehicle), the signified (tenor) and the foundation representing the feature similar to both compared objects. The sentences where all three components of similes are present can be found in the following cases: I bolted like a rabbit. My old man ...light as a monkey. In translation of these similes the translators managed to find precise Russian analogues.

Very frequently the translators have to resort to additions to metonymic foundations of similes: You dropped down like a bird.—padayesh kamnem vniz, tochno ptitsa (dropped stone-like down like a bird).

\subsection{Translation of Epithets and Other Figures of Speech}

While translating other tropes and figures of speech translators are bound to resort to grammatical and lexical replacements. This rule is operating for translation of epithets which emphasize emotional and expressive meaning. Due to this function of epithets the adequate perception of the text greatly depends on keeping intact the semantics and emotional load of epithets in translation and on the degree of faithful conveyance of poetic form and content of Hemingway's stories. The highly professional translators of the abovementioned stories artfully translated the epithets without any change of imagery and emotional coloring. Nevertheless, the translation of inverted epithets which do not have analogues in Russian are of special interest:

\section{$A$ hell of a fine lion-zamechatelniy lev (a fine lion)}


To translate adequately the figures of speech, as well as phonetic stylistic devices, such as onomatopoeia and alliteration, the translators frequently had to add emotionality to the origin, which resulted in inflated imagery in the text of translation. And quite the opposite, with the neutralization of stylistically marked elements the adequacy of emotional impact on the reader is achieved by means of translation compensation. However, not all the cases of compensation could be done without translation losses.

Concerning the realias the stories contain, mention should be made of the lexical units mostly referring to the objects and traditions connected with the bull fights in Spain. The original stories have no explanations of some realias and the majority of borrowed words are presented only by means of transliteration. In Russian translation the reader can find the commentaries with the explanation of such realias, as monos, cuadrilla, barrera, puntillo, muleta. The last word is not translated at all, it is transliterated in Russian translation, as the context prompts the meaning. Some realias have been conveyed by means of Russian equivalents or analogues. These words are familiar to the Russian speaking readers and don't need any explanation: torero, picador, matador.

\section{Conclusion}

Hemingway's creative activity keeps attracting attention of scholars and readers at all times. The linguistic analysis can include analysis from the stylistic point of view. Stylistic element is also present in comparative analysis of translation. Summarizing the main features of E. Hemingway's style which obviously stand out in his short stories, several major peculiarities are worth mentioning, and first of all, the idiosyncratic composition and unusual cohesion between the parts of the stories. The abundant resort to implicatures, understatements and symbols is also a distinguishing feature of these stories. Grammatical peculiarities include predominantly short, simple sentences which contribute to tensioning of the plot that often ends in tragic climax. Hemingway's manner of outlining his characters embraces a wide range of linguistic means: specific way of introducing dialogues, authentic speech of characters with colloquial words, ungrammatical use of structures and foreign words to show their national belonging.

As for Hemingway's stylistic preferences, in spite of some critics' opinion, I would like to say that his stories are distinguished by their peculiar use of figures of speech and syntactic stylistic devices. The remarkable epithets are based on various metaphors and metonymic phrases. Besides these wide-spread figures of speech Hemingway artfully uses similes, antonomasia, oxymoron, antithesis and phonetic stylistic means, such as alliteration, assonance, and onomatopoeia.

The main outcome of research done for the article is based on comparative translation analysis, where the comparison of the original and the translation into Russian is undertaken. Such analysis is to determine the level of adequacy of translation done by the professional translators into Russian. Despite slight losses due to natural reasons of differences in the systems of the two languages and for the purpose of complying with the norms of the translated language, the translators managed their task perfectly, with the high level of adequacy. Adequacy in perception of the original imagery is reached because the translators had to decorate or neutralize some original elements or resort to compensation. The translation into Russian sounds quite natural and the translated stories are read with great interest by the targeted readership.

\section{References}

Ardat, A. K. (1980). The Prose Style of Selected Works by Ernest Hemingway, Sherwood Anderson, and Gertrude Stein. Style, 14(1).

Atkins, J. (1952). Ernest Hemingway: His Work and Personality. Cambridge.

Baker, M. (2008). In Other Words: A Coursebook on Translation. London \& New York: Routledge.

Bassnett, S. (2010). Translation Studies. New Accents. London \& New York: Routledge.

Benson, J. (1983). "Patterns of Connection and Their Development in Hemingway's "In Our Time". In M. S. Reynolds (Ed.), Critical Essays on Ernest Hemingway's "In Our Time”. Boston.

Black, E. (2006). Pragmatic Stylistics. Edinbourgh Textbooks in Applied Linguistics. Edinbourgh: Edinbourgh University Press.

Bradford, R. (2010). Stylistics. The New Critical Idiom. London \& New York: Routledge.

Burhans, C. (1983). The Complex Unity of "In Our Time”. In M. S. Reynolds (Ed.), Critical Essays on Ernest Hemingway's "In Our Time”. Boston: G. K. Hall.

Cohen, M. (2005). Hemingway's Laboratory: The Paris in our Time. Rocky Mountain Review of Language \& Literature, 60(2), 78-80. 
Eco, U. (2001). Experiences in Translation. Toronto: University of Toronto Press.

Fedorov, A. V. (1968). Basics of General Theory of Translation. Moscow.

Fenton, C. (1996). The Apprenticeship of Ernest Hemingway. New York.

Galperin, I. R. (1977). Stylistics. Moscow, Higher School.

Goodman, P. (1974). The Sweet Style of Ernest Hemingway. In L. W. Wagner (Ed.), Ernest Hemingway. Five Decades of Criticism. Michigan.

Grebstein, S. N. (1974). Hemingway's Craft. Illinois.

Halliday, E. M. (1964). Hemingway's Ambiguity: Symbolism and Irony. In R. Weeks (Ed.), Hemingway: A Collection of Critical Essays. Upper Saddle River, NJ: Prentice-Hall.

Hatim, B., \& Munday, J. (2004). Translation: An Advanced Resource book. London \& New York: Routledge.

Hemingway, E. (2003). The Complete Short Stories of Ernest Hemingway (Finca Vigia Edition). New York: Charles Scribner's Sons.

House, J. (2009). Translation: Oxford Introductions to Language Studies. Oxford: Oxford University Press.

Komissarov, V. N. (2002). Modern Translation Studies. Moscow.

Kukharenko, V. A. (1979). Text Interpretation. Leningrad, Prosvesheniye.

Leech, G., \& Short, M. (2007). Style in Fiction: A Linguistic Introduction to English Fictional Prose. London: Longman-Pearson.

Levin, H. (1962). Observations on the Style of Ernest Hemingway. In R. P. Weeks (Ed.), A Collection of Critical Essays. Upper Saddle River, NJ: Prentice Hall.

Newmark, P. (1988). Approaches to Translation. Upper Saddle River, NJ: Prentice Hall.

Nord, C. (1991). Text Analysis in Translation: Theory, Methodology, and Didactic Application of a Model for Translation-Oriented Text Analysis. Amsterdam-Atlanta: Rodopi.

Scott, N. (1974). Ernest Hemingway. A Critical Essay. In L. W. Wagner (Ed.), Ernest Hemingway: Five Decades of Criticism. Michigan: Michigan State University Press.

Shen, D. (2005). What Narratology and Stylistics Can Do to Each Other. In J. Phelan \& P. Rabinovitz (Eds.), $A$ Companion to Narrative Theory. Oxford: Blackwell Publishing. https://doi.org/10.1002/9780470996935.ch9

Slabey, R. (1983). The Structure of "In Our Time." In M. S. Reynolds (Ed.), Critical Essays on Ernest Hemingway's "In Our Time". Boston.

Wales, K. (2001). A Dictionary of Stylistics (2nd ed.). Harlow: Longman.

\section{Copyrights}

Copyright for this article is retained by the author(s), with first publication rights granted to the journal.

This is an open-access article distributed under the terms and conditions of the Creative Commons Attribution license (http://creativecommons.org/licenses/by/4.0/). 